\title{
Overlap between Humanities Faculty Citation and Library Monograph Collections, 2004-2009
}

\section{Charlene Kellsey and Jennifer Knievel}

The authors wished to evaluate whether their collection housed the resources that their humanities faculty needed (and actually used) for their research, with the hope of providing additional illumination about general resource use by humanities scholars. This study asks not whether anyone used what was already owned, but instead whether the library owned what was needed. The answer to this question might have implications for storage or weeding decisions, approval plans for collections, and interlibrary loan. A citation analysis of 28 monographs published by their institution's humanities faculty between 2004 and 2009 was used to assess how many of their cited sources were owned, how they were acquired (approval or firm order), their average age, and interdisciplinary usage as evidenced by LC classification. Subject areas assessed were History, Philosophy, Classics, and English. Findings include that one quarter of sources cited were over 25 years old, and that over the last fifteen years, the approval plan has provided more than three quarters of the sources cited that were owned.

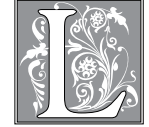

ibrarians who participate in collection development must necessarily make deliberate choices about what they do and do not collect. The literature of the field comprises many different angles that are relevant to collection development, from theoretical to anecdotal to statistical. Citation analysis is one methodology for studying what resources scholars use in their published work, while circulation statistics provide information about what materials in a library's collection are used. This study analyzes collections from a citation perspective, in an attempt to an- swer this question: Did the library own the monographs that the scholars used?

Answers to the question might tell us more about how to develop collections for the humanities, since the question asks not whether anyone used what we already own, but instead whether we own what was needed. By extension, the answer to this question might have implications for interlibrary loan, storage, or weeding decisions. Potentially this question might even influence approval plans for collections. The authors wished to evaluate whether our collection houses the resources that our humanities faculty 
needed (and actually used) for their research, with the hope of providing additional illumination about general resource use by humanities scholars. The authors expected to find that most of the works cited by humanities scholars at our institution were owned by the library, based on the fact that the collection is large and intended to support high-level research in all the disciplines studied.

A second question that this study will evaluate is how age is related to usefulness, at least as evidenced by citations to a work. Most libraries are not adding space and are forced by space constraints to reduce the size of their collection either by transferring to storage or withdrawing titles. Age of a resource is often one of the primary factors used in those decisions. Other studies have shown varying numbers about the age of works checked out of the collection (see the literature review below); data from this study will provide consistent parameters for comparison among the fields examined. We expected to find a wide range of ages of materials used, based on research others have done showing that humanists in particular tend to use older materials than scholars in other disciplines.

At many institutions, one of the principal means of purchasing monographs is through vendor approval plans. This study further seeks to evaluate how many of the works cited by humanities scholars were purchased via the approval plan, as opposed to direct ordering. This does not represent a thorough analysis of the concept of an approval plan; instead, it provides an analysis of what was used by this group of scholars and whether that factor was related in a relevant way. The library's approval plan is primarily for English language monographs; thus, the authors hypothesize that disciplines heavily citing foreign language might have a lower rate of materials purchased via approval plans than disciplines citing predominantly English language materials. We expected, nevertheless, to find that the majority of books in our collection cited by our scholars arrived in the collection via approval, given that over half of our annual monograph purchases are acquired in that fashion, and the approval plan is set up specifically to acquire the most important and relevant titles being published in the academic fields represented in the university.

Several existing citation studies have compared the rate of citations to monographs as opposed to journal articles; however, for several reasons, the majority of those studies analyze the citations found in journal articles. Some evidence suggests the rate of citations to books is higher in books than it is in journals. This study attempts to provide further analysis of that question by looking at rates of citations in monographs to journal articles and monographs. Those numbers will be compared to similar studies based on citations in journal articles in the same disciplines.

An additional question of interest was whether the monograph authors cited a substantial number of works outside their field, as indicated by the Library of Congress (LC) classification of the work cited. While LC classification has limitations as an indicator of the subject of a work, it does attempt to group titles by the main subject of the work; thus, it might provide some basic data about the interdisciplinarity of work being done by humanities scholars.

This study focuses only on faculty as a user group, since they usually drive the direction of research at a research university. Graduate students would also be a relevant population for study of this question, and an analysis of dissertation citations would make a valuable complementary study, but the works of graduate students were not included in this study.

\section{Literature Review}

Citation analysis as a methodology for analyzing perceived quality or impact of the work has proponents and detractors in the information science literature. The use of citation analysis for evaluating 
use of materials, however, seems less problematic, since it can be assumed that, if a scholar cites a work, it has been used in some manner to inform that scholar's work. ${ }^{1}$ There is a large literature of citation analysis studies for the humanities and for specific fields within the humanities. ${ }^{2}$ Most of the studies analyze citations in important journals in the fields selected, because they come out on a regular basis and cover all aspects of the field in question, and they can be studied over a time period to study trends. For humanities fields that are known to be monograph-dependent, this methodology can be problematic. Although the studies do show more use of monographs than journal articles, based on the citations in journals, it is not clear whether citation practice in monographs, the primary mode of publication for humanists, is the same.

Few citation studies of monographs have been done, mostly due to the difficulty of selecting an appropriate group of monographs to study. Because monographs tend to treat specific aspects of a particular subject within the field at large, studies of a small group of monographs may not represent the wider variety of practice within the field, so larger samples need to be gathered. McDonald identified 173 publications published from 1994 to 2000, by forty-six authors in the social sciences and humanities at his institution, with a total of 11,852 citations. ${ }^{3}$ Of these, only twenty-one publications were books, but they contained almost half of the citations $(5,521)$, averaging 262 per book. By contrast, the 5,112 citations in the 152 journal articles averaged thirtythree per article. Most of his results are not broken out by disciplines and include items in both the humanities and social sciences; however, in table 9 he shows cited references by discipline, including history (57\% books, 39\% journal articles, $4 \%$ other), literature (78\% books, $16 \%$ journal articles, $6 \%$ other) and philosophy (44\% books, $54 \%$ journal articles, $2 \%$ other). These results are not broken out by whether the citing source was a book or a journal article; however, table 8 breaks out citing source and cited format by publication year. There is considerable variation over the different years; but, in all cases except one, books cite books more often (sometimes by a large margin), and journal articles cite journal articles more often. This result certainly underlines the need to conduct citation analysis of monographs in monographdependent fields such as the humanities in order to gain a true picture of the needs of scholars.

A recent qualitative study by Williams et al. on "The Role and Future of the Monograph in Arts and Humanities Research," consisting of in-depth interviews with seventeen arts and humanities academics, notes the surprising paucity of studies of the monograph in the literature, considering its importance to arts and humanities fields. ${ }^{4}$ Their "overall results suggested the monograph remains the single most valued means of scholarly publication and communication within the $\mathrm{A} \& \mathrm{H}$ field and is widely seen as essential in making career progress." 5 Many said that monographs were more subject-specific and specialized, which is important to other academics in their own research. Many also said that they use monographs with students, even undergraduates, as an important way of teaching them to concentrate, reflect, and take their time with an extended argument. The authors note that this was a pilot study in preparation for a large-scale project to consider the entire scholarly infrastructure that supports monograph writing and publishing in the arts and humanities, one that is certainly needed in this time of transition in the publishing world.

Another recent study shows the consistency over time of the proportion of citations to books versus to journal articles. Lariviere's study, although based on citations in journal articles, shows little change (with a minor bump up in the mid-1980s) from 1981 to 2000 in citations 
to journal articles in history (around 34\%), literature (around 24\% in 1981, declining to $21 \%$ in 2000) and "other humanities" (around 26\%). ${ }^{6}$ While the actual numbers in that study may not be strictly comparable to the current study, the consistency over time does indicate that the monograph continues to be most important in the humanities.

Knievel and Kellsey, in their study of eight humanities fields, found the following book/journal proportions in citations from major journals in each field: Classics (76.8\% books, $23.2 \%$ journal articles), English (83\% books, $17 \%$ journal articles), History $(76.4 \%$ books, $23.6 \%$ journal articles), and Philosophy (51.4\% books, $48.6 \%$ journal articles). ${ }^{7}$

Studies of individual fields include Thompson's examination of literary scholarship in which she examined 6,708 citations from eight monographs and four journals. ${ }^{8}$ Results are separated by whether the citation was to a primary source or a secondary source, and by whether the citing source was a book or journal article. Books cited primary source monographs 85.43 percent and secondary source monographs 67.58 percent, while journals cited primary source monographs 67.45 percent and secondary source monographs 66.22 percent. Thompson also studied the age of the source cited and found that 77.7 percent were 25 years old or under, while 22.3 percent were over 25 years old at the time of the citation.

Heinzkill has also done a large study of 20,000 citations in 555 articles in literary journals. ${ }^{9} \mathrm{He}$ found the citations were 75.8 percent to books, 19.8 percent to articles, and that only 55.4 percent of them were less than twenty years old. He also found that over 40 percent of the citations to monographs were outside the core discipline of literary studies.

A study by John Cullars in the field of philosophy looked at 539 citations randomly selected from 183 single-authored books published in 1994 and indexed in Philosopher's index. ${ }^{10}$ Cullars counted multiple references to the same title, so his results are not strictly comparable to those of this study. He found that 84.6 percent of total citations were to books, whereas Knievel and Kellsey's study based on journal citations found only 51.4 percent citations to books and 48.2 percent citations to journal articles. ${ }^{11}$ The results of the present study should help to clarify the citation practice in philosophy. Cullars also looked at the LC classification of the citing books and found that only 80 percent of them were actually included in the philosophy class of $\mathrm{B}$. He also found that 25 percent of the citations counted were to nonphilosophy disciplines. He notes the subjectivity of LC classification assignment (as do the present authors), but this result is at least suggestive of the interdisciplinary nature of philosophy scholarship.

A recent study of approval plans in two ARL libraries looked at titles received during fiscal year 2005 and correlated circulation data to come up with circulations per title and cost per use broken down by subject areas and by publishers. ${ }^{12}$ They found that 31 percent of one and 40 percent of the other institution's approval books had not circulated within one to two years of acquisition. The authors of that study intend to continue gathering circulation data to see if the percentage of nonuse decreases over time and if the books used in the first year continue to circulate. The authors of the present study are assessing use from the point of view of the user, rather than overall circulation of a collection of titles, but the age of titles used that has been collected for this study may usefully inform future studies of collection use, since, in the humanities, one or two years seems to be an inadequate time period from which to draw valid conclusions regarding circulation of titles purchased on approval plans.

Beaubien's ARL white paper on interlibrary loan indicates that Association of Research Library (ARL) statistics, collected annually from the member libraries, show increasing levels of inter- 
library borrowing over the past nineteen years. ${ }^{13}$ She also cites National Center for Education Statistics (NCES) showing a 26 percent increase in borrowing for returnable items (usually books) in the period from 1998 to 2004, while there has been a corresponding decline in borrowing of nonreturnable items of 4 percent, probably due to the increasing availability of full-text articles through library journal package and backfile electronic subscriptions. Henderson posits that interlibrary borrowing indicates a failure of the library's collection to meet user needs and that recent increases are due to declining financial support and purchasing power of library materials budgets. ${ }^{14} \mathrm{He}$ criticizes the "access not ownership" model espoused by library and university managers as deliberately excluding costs to users and to the quality of users' work, believing that it has contributed to the cost spiral of publishers increasing prices as total sales decline.

Most studies in the library and information science literature understandably look at collections, the age of materials, and their usage from a library point of view. They are concerned with cost per use, percentage of the collections that do not circulate, or citations as indicators of the impact of the item in question. Interlibrary loan studies look at what was requested and by whom or at the number of items borrowed correlated with collection size. While these are all valuable studies, the present study is approaching the issue from the user's point of view. How much of what humanities faculty use for their research is regularly purchased for the collection, how was it acquired, how old are the materials they use, and do they use materials from disciplines other than their own? Studies such as the Council on Library and Information Resources "Scholarly Work in the Humanities and the Evolving Information Environment" give an interesting insight into how humanities scholars conduct their research with texts and monographs, but there seems to be little in the library literature on how well libraries are doing in supplying the resources that humanities scholars need for their research. ${ }^{15}$ It is hoped that the current study will contribute to filling that gap in the literature.

\section{Method}

Since the goal of this study was to evaluate whether or not the library owned the materials used by scholars on campus, the authors chose to evaluate the works cited in research monographs published in a six-year period by faculty on our campus in four disciplines: History, English, Classics, and Philosophy. Creative monographs such as works of fiction and poetry were excluded. Of the eighty-eight books published by faculty in the four departments, twenty-eight books fit these criteria. In History, nine books were used for the study, while we excluded seven edited volumes and five with no bibliography. In English, seven books were used, and we excluded eight edited volumes or textbooks, two with no bibliography, and twenty-seven novels, plays, or volumes of poetry; creative writing is a focus of the department. In Philosophy, nine books were used, while three edited volumes, one children's book, and two with no bibliography were excluded, as well as three works cowritten with authors from other institutions (since we have no way of assessing which author used which sources). Classics is a smaller department and had three books that were used for the study, and one critical edition was not used because it did not include a bibliography of secondary sources.

Books published by authors who were at CU during the five-year period but subsequently left were not included, because information about faculty who left and what years they were here proved very difficult to find. Additionally, we did not attempt to determine whether current faculty were at CU when they wrote their books, again because information about that point was very difficult to acquire, short of interviewing each faculty member about each title they published. 
Similarly, we were not able to identify whether the book was in the collection before the faculty member cited it, or whether it was acquired subsequently. The goal of the study was to identify whether the collection matched the needs of the scholars; thus, it made sense to include works cited in the specified time period from all current faculty. Most of the faculty whose published works were included in this study had been with the institution for some time, so these caveats apply to very few cases.

The authors analyzed the works cited in all qualifying books published in the years 2004 to 2009 in the four disciplines. One title (Hunt) from January 2010 was included for Classics, because we had so few titles for that field. As is always the case with citation analyses, the authors made several choices about citations to include or exclude in the study. These decisions were made based on the study goals and characteristics of the resources. Each citation was evaluated to determine if it cited a book or a journal, and whether or not the work cited was in English or not in English. Works in translation were cited in the language into which they were translated (thus, a citation to an English translation of a French philosophical text was tallied as English, since that was the language of the material actually used). Chapters or articles in edited compiled volumes were counted as books, and counted in the language of the cited chapter or article, not the language of the volume. Books with multiple citations in one bibliography (to multiple chapters, for example) were counted only once, since that would measure intensity of use instead of availability. Proceedings were counted as books or journals depending upon how they were published (they were mostly counted as books). Newspaper articles and encyclopedia entries were counted as journal articles. Evaluating the entire universe of humani- ties faculty research habits is beyond the scope of this study, which focuses on published secondary sources; therefore, law cases, dissertations, archival materials, unpublished proceedings, Classics primary source collections, and other unpublished works were not counted. CU is a regional, federal, and UN depository, and thus it can be generally assumed that we own all government documents except in unusual cases of missing or lost materials. Therefore, determining whether or not we owned cited government documents did not provide the enlightenment this study sought, so government documents were not counted.

Once each entry was identified as a book or journal, the books were checked against the local library catalog to determine: 1) if the book was owned by the library; 2) the call number (CU uses LC classification); 3) the publication date; 4) whether it was ordered directly or via approval; and 5) whether the copy owned was electronic or print. There were too few electronic versions found to be usefully discussed, though this could change in the future as e-books become more common in the humanities. Only the exact editions cited were considered a match; if the library owned the same title in a different edition, it was not marked as a title we owned. Many records, especially for older titles, did not indicate the method of purchase, so it could not be determined if they were purchased directly or via an approval plan.

The total number of citations counted was 8,127 in 28 books. The resulting data

\begin{tabular}{|l|c|c|c|}
\hline \multicolumn{4}{|c|}{ TABLE 1 } \\
\hline Number of Citations \\
\hline Subject & $\begin{array}{c}\text { Number } \\
\text { of Books }\end{array}$ & $\begin{array}{c}\text { Total } \\
\text { Citations }\end{array}$ & $\begin{array}{c}\text { Avg Citations } \\
\text { per Book }\end{array}$ \\
\hline History & 9 & 2,390 & 266 \\
\hline Philosophy & 9 & 2,560 & 284 \\
\hline English & 7 & 1,606 & 229 \\
\hline Classics & 3 & 1,571 & 524 \\
\hline Total & 28 & 8,127 & 290 \\
\hline
\end{tabular}


were grouped by discipline to facilitate more meaningful interpretation and analyzed in comparison with the other disciplines and in the aggregate. The small number of books from Classics presents a difficulty in the data, since three books are probably not representative of the total faculty in the department. The authors nevertheless chose to include the data despite these weaknesses because of the large number of citations in the three books indicating a high use of library resources, and its usefulness in assessing our ownership of the resources these scholars required.

The average of 290 citations per book is comparable to the 262 citations per book found by McDonald in his study. ${ }^{16}$

\section{Results and Discussion}

The data show that overall 69 percent of the citations collected were to books, while 31 percent were to journal articles. It was found that 76 percent were in the catalog as owned, while 24 percent were not. Only about 21 percent of the titles in the catalog had order records, since these are only available in the current integrated library system (ILS) back to 1995; but, of the titles that had order information, 81 percent were purchased on the approval plan, while only 19 percent were firmordered.

This confirmed the expectation that a majority of the titles cited would be
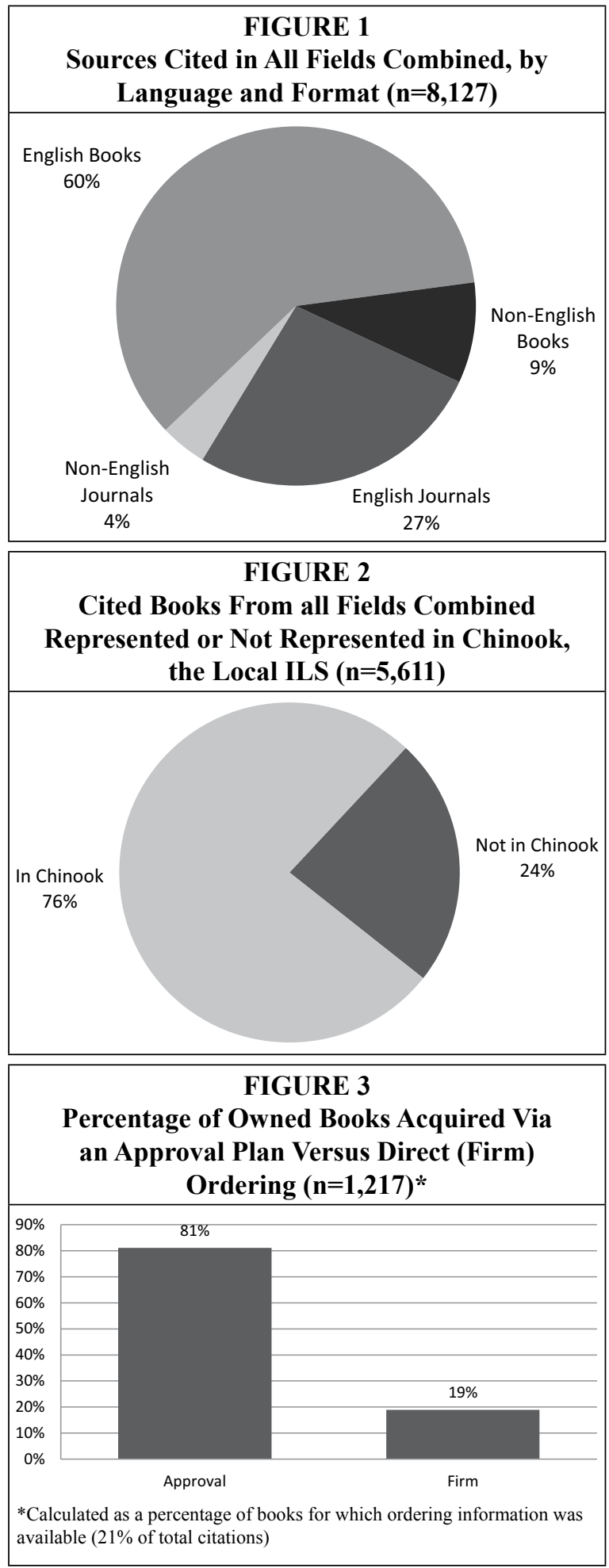


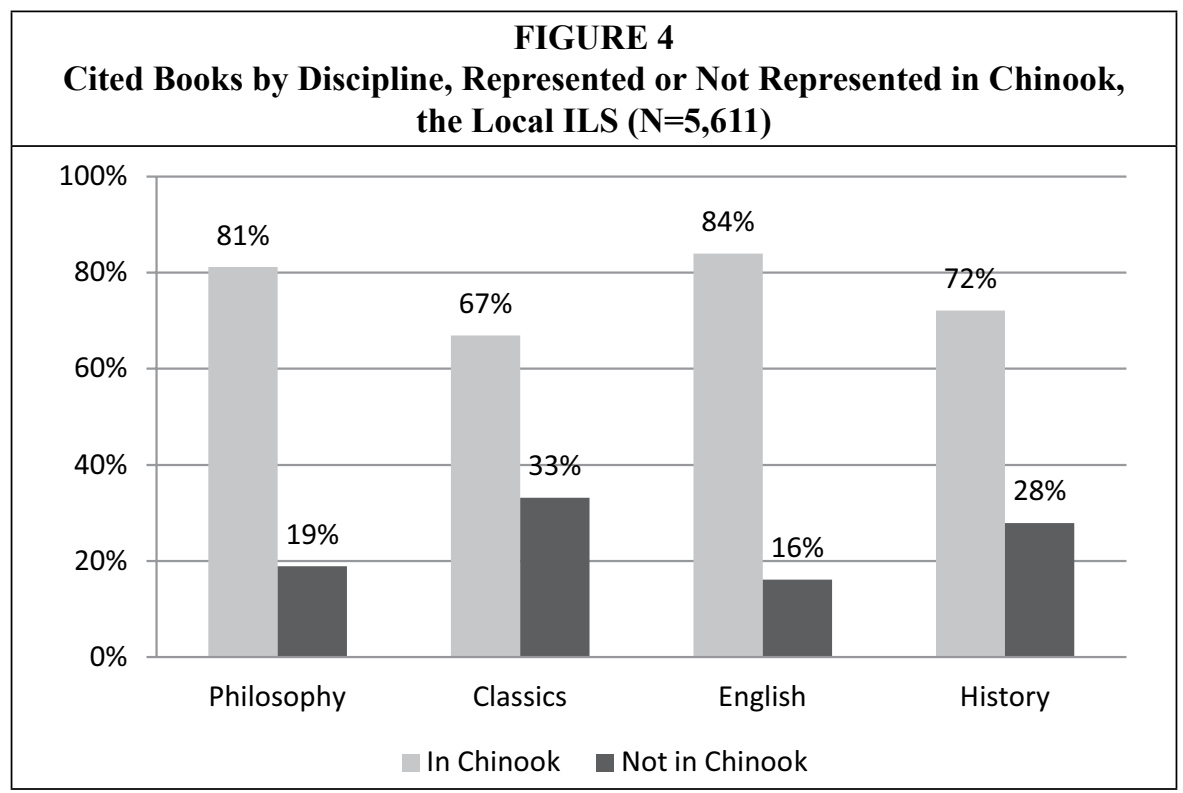

found in the library's collection and that a majority had come on the approval plan, at least in the last fifteen years. The fact that almost one quarter of the monographic titles cited were not owned by the library, however, indicates a substantial reliance by humanities faculty on interli- brary borrowing, personal collections, or other means, for the resources they need for their research (not including primary sources found in archival collections).

The overall average does not tell the entire story, though, since considerable variation was found among the four

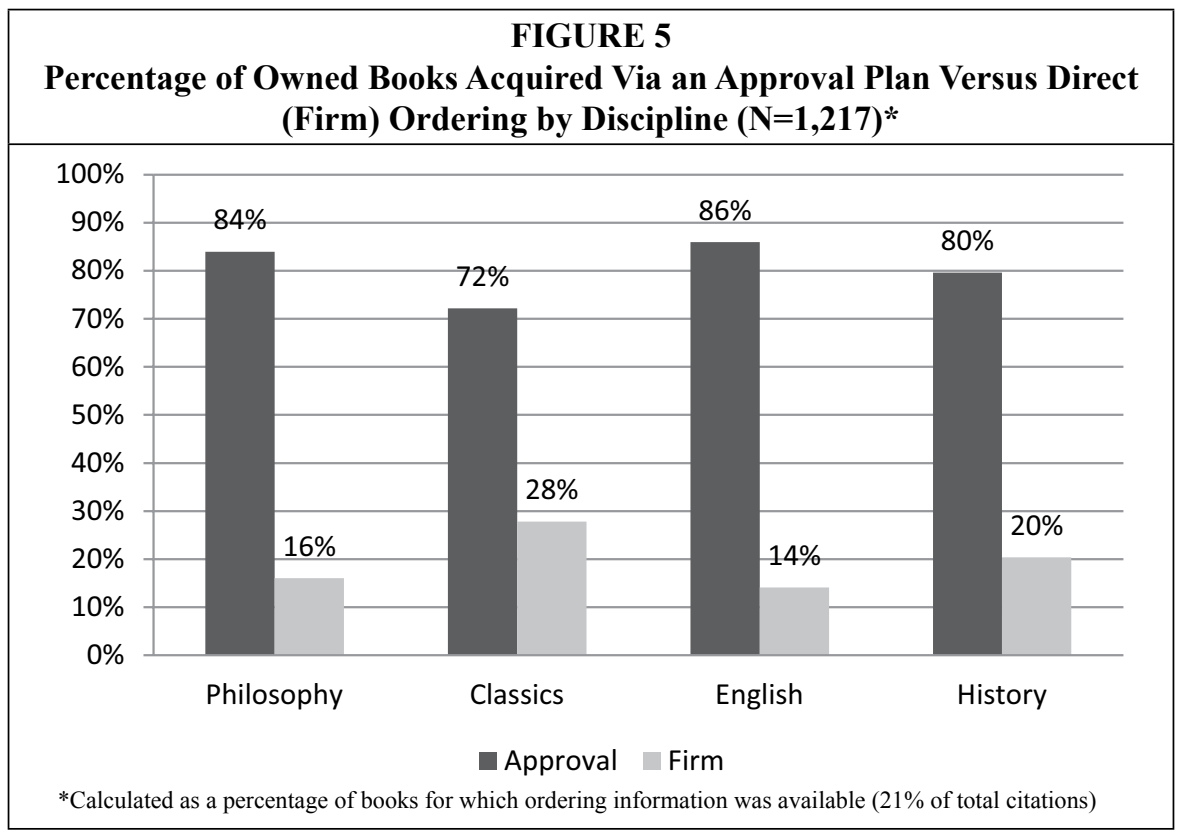


fields examined. The percentage of items owned ranged from a low of 67 percent for Classics to a high of 84 percent for English, with History at 72 percent and Philosophy at 81 percent.

The proportion of items received on the approval plan in the last fifteen years ranged from 72 percent for Classics to 80 percent for History, 84 percent for Philosophy, and 86 percent for English. A possible explanation for the higher percentage of items owned and received on the approval plan for English literature and Philosophy may be that those fields deal with a recognized canon of authors' texts and criticism about them, primarily written in English, making it easier for libraries to collect systematically in those fields, while History covers a vast range of topics, geographical areas, languages, and time periods making it more difficult to collect as comprehensively. The source monographs in Classics used for this study were mostly on topics outside the canon of traditional Greek and Roman authors, which may have contributed to the lower percentage of titles owned and those received through the approval plan. The high percentage of non-English books used in Classics (19 percent of total books cited) is probably also a contributing factor, since the main approval plan covers mostly English language books; by contrast, in the other fields, citation of nonEnglish books is much less (History 13\%, English 3\%, Philosophy 3\%).

The age of the resources cited for two of the fields followed a trend of the peak number of items used being in the range of six to ten years old, with a gradual decrease out to twenty-five years. In History and Classics, the peak number of items was in the eleven- to fifteen-year range. For Philosophy and History, the number of items used that were the most recent, five years or fewer, was the smallest percentage of any of the time periods, including twenty-one to twenty-five years old; for English and Classics, the percentage of the most recent items was only slightly larger than that of the items that were twenty-one to twentyfive years old. Thus, noncirculation within the first few years as a criterion for the success of approval plans needs to be considered with caution, based on these data for humanities fields. For all of the fields, items that were more than twenty-five years old at the time of use

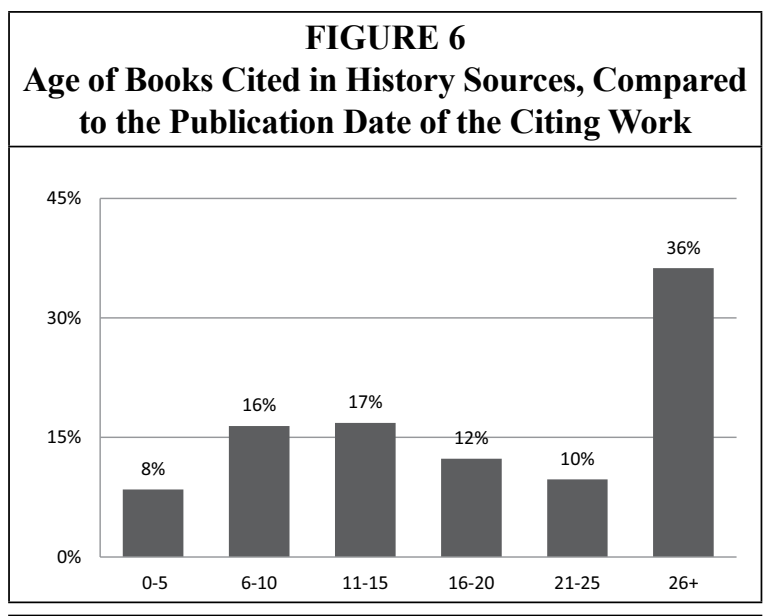

FIGURE 7

Age of Books Cited in Philosophy Sources, Compared to the Publication Date of the Citing Work

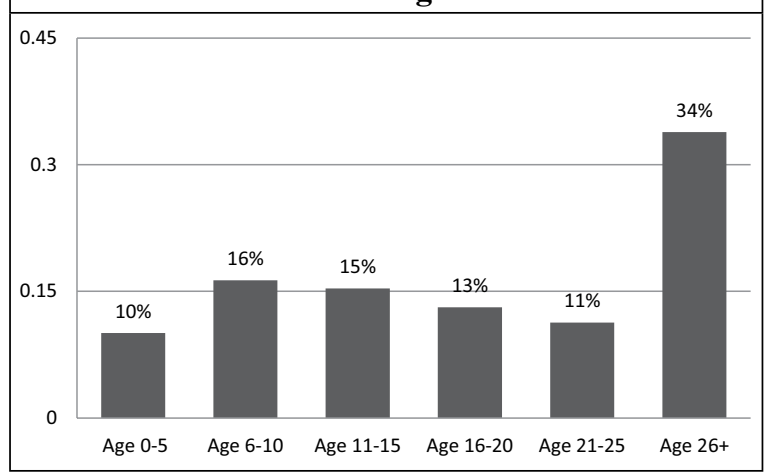



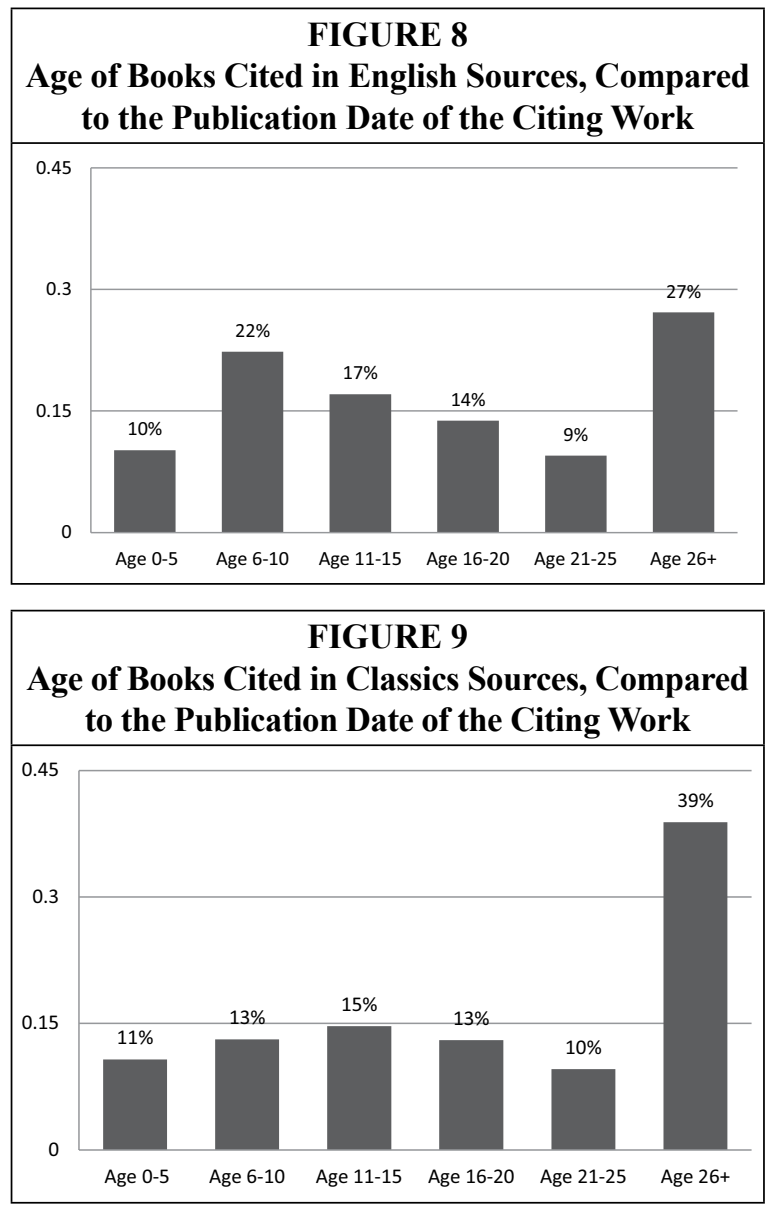

represented a substantial percentage of items used, from 27 percent for English, 34 percent for Philosophy, 36 percent for History and up to 39 percent for Classics. These results diverge from fields where the greatest usage is in the first five years and suggests that considerable caution needs to be exercised when making weeding or storage decisions based on date of publication.

It can be seen graphically in figure 10 that the fields of History and Classics tend to use older materials than English and Philosophy, on average. Averages need to be looked at cautiously, since a few outlying dates can skew the average, but this chart is certainly suggestive of the relative use of older materials among the four fields studied.

As mentioned in the literature review above, most citation analysis studies use articles in journals as the citing source for their studies. The authors wondered whether the proportion of books versus journals cited would differ when the citing source was monographs, the most important publication venue for humanities scholars. Table 2 compares the results for the four fields found in Knievel and Kellsey that studied citations in journals with the results of the current study. ${ }^{17}$ While the fields of history and philosophy do show greater use of monographs when monographs are the citing source, English shows almost the same result for both, and Classics shows greater citing of monographs in the journal articles than in the monographs. The result for Classics

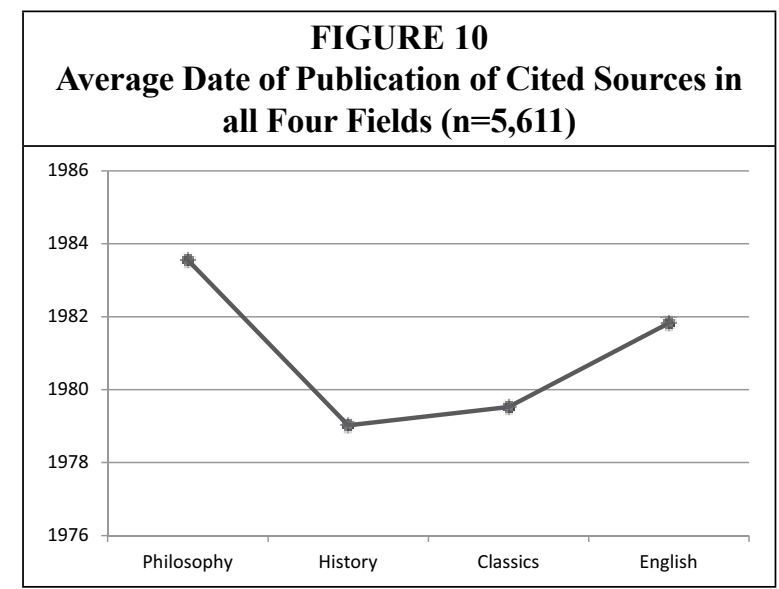




\begin{tabular}{|l|c|c|c|c|}
\hline \multicolumn{5}{|c|}{ TABLE 2 } \\
Books Cited by Books or Journals, and Journals Cited by Books or Journals
\end{tabular}

may again be due to the small number of monographs studied; a larger sample should be studied before drawing conclusions in that field.

The classification letters of the cited monographs were collected when the titles were searched in the catalog, as a rough indication of the subject field of those sources. The call number assigned is supposed to reflect the overall topic treated in the book, so the authors felt that these data might provide information concerning whether the research currently being conducted by humanities faculty is interdisciplinary. Use of books in call number ranges outside the principal one for the field varied by discipline, but all of the fields showed substantial use of sources in other disciplines. Twenty-seven percent of the citations in the monographs in philosophy, which has a well-defined call number range in the LC classification schedule of $B$, were to works outside that range, mostly in $\mathrm{P}$ (literature) and $\mathrm{Q}-\mathrm{V}$ (science). One of the three source works in Classics happened to treat the works of Jerome, an early Christian leader whose works class in the religion range in $\mathrm{BR}-\mathrm{BX}$, rather in the usual $\mathrm{PA}$ or Ds of ancient literature and history, but many of the cited sources were in $\mathrm{G}-\mathrm{K}$ (social sciences). History covers a broad range of call numbers, from $C$ through $F$, depending on geographic area of the subject treated; even so, 37 percent of the citations analyzed for the history monographs fell outside the $\mathrm{C}-\mathrm{F}$ range, mainly in $\mathrm{G}-\mathrm{K}$ and $\mathrm{P}$. One would expect monographs on English literature topics to fall mostly in the PN, PR, and PS classes; but, in the English monographs examined, over half of the citations (56\%) fell in other call number ranges, roughly evenly split among $B$, $\mathrm{C}-\mathrm{F}$, and $\mathrm{G}-\mathrm{K}$. The surprisingly large percentages of works used outside the main call number ranges for all of the fields seems to confirm the interdisciplinarity of work in the humanities and argues for awareness on the part of selectors of these needs by the faculty in their departments.

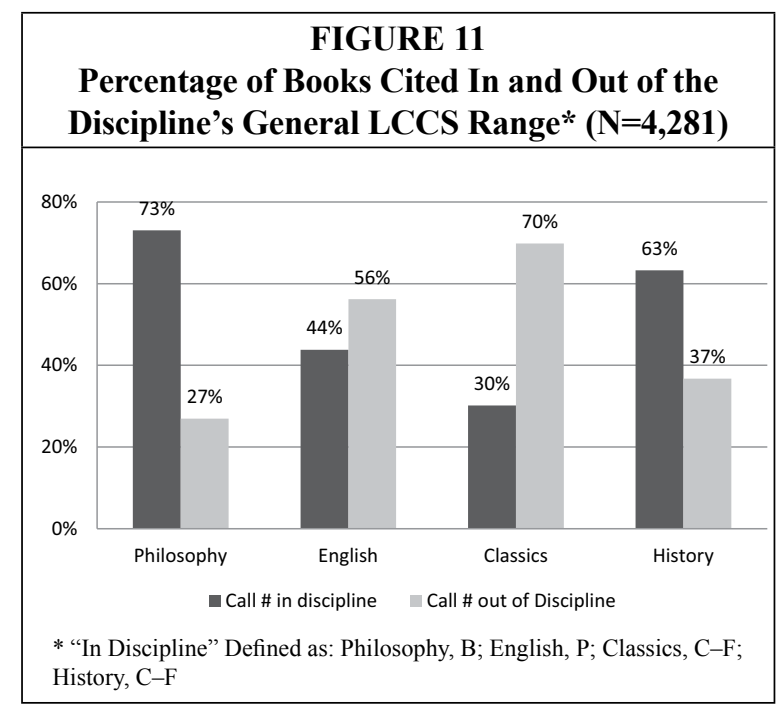




\section{Conclusion}

Results of this study of citation practice in monographs published by humanities faculty tended to confirm the authors' expectations - although there were some unexpected findings, as well as variation in results among the four disciplines studied. On the whole, the library did own 76 percent of the books cited by the humanities faculty, while 24 percent were not owned by the library. Since comparable studies of this factor could not be found in the literature, it is difficult to know what the norm is for comparable research libraries, and further research on this factor would be desirable. The fact that almost one quarter of the monographs cited by humanities faculty in their research were not owned by the library certainly has implications for collection development and interlibrary loan, but further analysis of the titles not owned would be needed before any generalizations could be made about the causes for this deficiency.

Data gathered on the publication dates of books cited in the monographs studied show a range of dates, with 27 to 39 percent of the sources cited being over twenty-five years old at the time they were cited. It cannot be assumed, therefore, that items over twenty-five years old are not used and thus should be weeded or moved to storage. Equally interesting is the fact that only 8 to 11 percent of the items used were within their first five years since publication; all four fields studied showed higher use in years $6-10$ and $11-15$. This may be partly explained by the time required by scholars to write a book and get it published, so that the titles they cite are a little older by the time the citing book comes out. Time for reviews to appear in the trusted journals may also contribute to the time lag. This does argue, however, for caution in evaluating usefulness of items purchased by the library after only a year or two of circulation history.

Data gathered regarding whether books cited were purchased on the approval plan or by firm order was limited by the fact that these data have been available in the ILS only for the past fifteen years. Purchase data were available for only 21 percent of citations gathered; nevertheless, of the items cited for which purchase data was available (those owned by the library, and purchased since 1995), 81 percent were purchased on the approval plan while only 19 percent were firm-ordered (see figure 5 for variations by discipline). More data and further study of use of the approval plan books would be welcome, but this result is an indicator that approval plan purchasing, in these four humanities fields at least, is securing a large proportion of the newly available resources needed by scholars.

The call number data gathered should be understood as only a rough indicator of use of titles outside the author's discipline, but the fact that all four fields showed a substantial percentage of this use (see figure 11) is also interesting. Additional studies of humanities monographs, and more detailed methodology for identifying interdisciplinary use, would certainly be warranted to see how widespread the phenomenon is and whether it is increasing over time.

This study has attempted to approach the use of monographs in libraries by humanities scholars, from the perspective of what the scholars used in their published work. While interesting results have been presented, the authors encourage others to replicate the study using their own collections and their faculty's published work so that a larger base of data becomes available upon which to draw conclusions. 


\section{Appendix 1}

The purpose of this appendix is to facilitate future comparison studies of other collections. While these data have already been presented in the form of percentages and in the discussions, we hope that authors interested in pursuing future studies will find the raw data included below useful to them.

\begin{tabular}{|l|c|c|c|c|c|c|c|c|c|}
\hline \multicolumn{10}{|c|}{ HABLE 3 } \\
\hline Subject & $\begin{array}{c}\text { English } \\
\text { Journals }\end{array}$ & $\begin{array}{c}\text { Non- } \\
\text { English } \\
\text { Journals }\end{array}$ & $\begin{array}{c}\text { English } \\
\text { Books }\end{array}$ & $\begin{array}{c}\text { Non- } \\
\text { English } \\
\text { Books }\end{array}$ & $\begin{array}{c}\text { Total } \\
\text { Citations }\end{array}$ & $\begin{array}{c}\text { Not in } \\
\text { Chinook }\end{array}$ & $\begin{array}{c}\text { In } \\
\text { Chinook }\end{array}$ & $\begin{array}{c}\text { Approval } \\
\text { Order }\end{array}$ & $\begin{array}{c}\text { Firm } \\
\text { Order }\end{array}$ \\
\hline Philosophy & 1,085 & 34 & 1,363 & 78 & 2,560 & 272 & 1,169 & 262 & 50 \\
\hline Classics & 423 & 188 & 669 & 291 & 1,571 & 318 & 642 & 161 & 62 \\
\hline English & 282 & 6 & 1,272 & 46 & 1,606 & 212 & 1,106 & 287 & 47 \\
\hline History & 384 & 114 & 1,571 & 321 & 2,390 & 528 & 1,364 & 277 & 71 \\
\hline All Subjects & 2,264 & 342 & 5,096 & 736 & 8,438 & 1,372 & 4,460 & 1,055 & 236 \\
\hline
\end{tabular}

\begin{tabular}{|l|c|c|c|c|c|c|c|c|c|}
\hline \multicolumn{10}{|c|}{ TABLE 4 } \\
\hline Subject & $\begin{array}{c}\text { Call \# } \\
\text { in B }\end{array}$ & $\begin{array}{c}\text { Call \# } \\
\text { in C-F }\end{array}$ & $\begin{array}{c}\text { Call \# } \\
\text { in G-K }\end{array}$ & $\begin{array}{c}\text { Call \# } \\
\text { in L-N }\end{array}$ & $\begin{array}{c}\text { Call \# } \\
\text { in P }\end{array}$ & $\begin{array}{c}\text { Call \# } \\
\text { in Q-V }\end{array}$ & $\begin{array}{c}\text { Call \# in } \\
\text { A or Z }\end{array}$ & $\begin{array}{c}\text { Call \# out of } \\
\text { Discipline }\end{array}$ & Total \\
\hline Philosophy & 834 & 11 & 49 & 3 & 120 & 125 & 0 & 308 & 1,142 \\
\hline Classics & 163 & 191 & 102 & 37 & 104 & 30 & 6 & 442 & 633 \\
\hline English & 124 & 207 & 184 & 54 & 472 & 27 & 9 & 605 & 1,077 \\
\hline History & 84 & 838 & 167 & 38 & 139 & 43 & 16 & 487 & 1,325 \\
\hline All Subjects & 1,344 & 1,247 & 504 & 133 & 837 & 259 & 31 & 1,881 & 4,355 \\
\hline
\end{tabular}

TABLE 5

Age of Resource Data: All Subjects

\begin{tabular}{|l|c|c|c|c|c|c|c|c|}
\hline \multicolumn{1}{|c|}{ Subject } & $\begin{array}{c}\text { Average Pub. Year } \\
\text { of Cited Works }\end{array}$ & $\begin{array}{c}\text { Age } \\
\mathbf{0 - 5}\end{array}$ & $\begin{array}{c}\text { Age } \\
\mathbf{6 - 1 0}\end{array}$ & $\begin{array}{c}\text { Age } \\
\mathbf{1 1}-\mathbf{- 1 5}\end{array}$ & $\begin{array}{c}\text { Age } \\
\mathbf{1 6}-\mathbf{2 0}\end{array}$ & $\begin{array}{c}\text { Age } \\
\mathbf{2 1 - 2 5}\end{array}$ & $\begin{array}{c}\text { Age } \\
\mathbf{2 6}+\end{array}$ & Totals \\
\hline Philosophy & 1,984 & 145 & 235 & 221 & 189 & 163 & 488 & 1,441 \\
\hline Classics & 1,980 & 103 & 126 & 141 & 125 & 92 & 373 & 960 \\
\hline English & 1,982 & 134 & 294 & 225 & 182 & 125 & 358 & 1,318 \\
\hline History & 1,979 & 160 & 311 & 318 & 233 & 184 & 686 & 1,892 \\
\hline All Subjects & 1,981 & 570 & 1,003 & 947 & 754 & 585 & 1,973 & 5,832 \\
\hline
\end{tabular}




\section{Books Evaluated for This Study}

\section{Philosophy}

Boonin, David. The Problem of Punishment. Cambridge, U.K., and New York: Cambridge University Press, 2008.

Forbes, Graeme. Attitude Problems: An Essay on Linguistic Intensionality. Oxford: Clarendon, 2006.

Hanna, Robert. Kant, Science, and Human Nature. Oxford: Clarendon Press, 2006.

- - - Rationality and Logic. Cambridge, Mass.: MIT Press, 2006.

Huemer, Michael. Ethical Intuitionism. Houndmills, Basingstoke, Hampshire, and New York: Palgrave Macmillan, 2005.

Koslicki, Kathrin. The Structure of Objects. Oxford and New York: Oxford University Press, 2008.

Lee, Mi-Kyoung. Epistemology After Protagoras: Responses to Relativism in Plato, Aristotle, and Democritus. Oxford: Clarendon Press, 2005.

Oddie, Graham. Value, Reality, and Desire. Oxford: Clarendon, 2005.

Rupert, Robert D. Cognitive Systems and the Extended Mind. Philosophy of Mind. Oxford and New York: Oxford University Press, 2009.

\section{English}

Forman, Valerie. Tragicomic Redemptions: Global Economics and the Early Modern English Stage. Philadelphia: University of Pennsylvania Press, 2008.

Green, Jeremy. Late Postmodernism: American Fiction at the Millennium. New York: Palgrave Macmillan, 2005.

Heydt-Stevenson, Jillian. Austen's Unbecoming Conjunctions: Subversive Laughter, Embodied History. New York and Basingstoke, Hampshire: Palgrave Macmillan, 2005.

Kelsey, Penelope Myrtle. Tribal Theory in Native American Literature: Dakota and Haudenosaunee Writing and Indigenous Worldviews. Lincoln: University of Nebraska Press, 2008

Labio, Catherine. Origins and the Enlightenment: Aesthetic Epistemology from Descartes to Kant. Ithaca: Cornell University Press, 2004.

Rivera, John-Michael. The Emergence of Mexican America: Recovering Stories of Mexican Peoplehood in U.S. Culture. Critical America. New York: New York University Press, 2006.

Toulouse, Teresa. The Captive's Position: Female Narrative, Male Identity, and Royal Authority in Colonial New England. Philadelphia: University of Pennsylvania Press, 2007.

\section{Classics}

Cain, Andrew. The Letters of Jerome: Asceticism, Biblical Exegesis, and the Construction of Christian Authority in Late Antiquity. Oxford Early Christian Studies. Oxford and New York: Oxford University Press, 2009.

Dusinberre, Elspeth R.M. Gordion Seals and Sealings: Individuals and Society. University Museum Monograph. 1st ed. Vol. 124. Philadelphia: University of Pennsylvania Museum of Archaeology and Anthropology, 2005.

Hunt, Peter. War, Peace, and Alliance in Demosthenes' Athens. Cambridge, U.K., and New York: Cambridge University Press, 2010.

\section{History}

Bruce, Scott G. Silence and Sign Language in Medieval Monasticism: The Cluniac Tradition c. 900-1200. Cambridge Studies in Medieval Life and Thought. Fourth Series. Vol. 68. Cambridge, U.K., and New York: Cambridge University Press, 2007. 
Chester, Lucy P. Borders and Conflict in South Asia: The Radcliffe Boundary Commission and the Partition of Punjab. Studies in Imperialism. Manchester, U.K., and New York: Manchester University Press, 2009.

DeLay, Brian. War of a Thousand Deserts: Indian Raids and the U.S.-Mexican War. The Lamar Series in Western History. New Haven: Yale University Press, 2008.

Kent, Susan Kingsley. Aftershocks: Politics and Trauma in Britain, 1918-1931. Basingstoke, England, and New York: Palgrave Macmillan, 2009.

Love, Eric Tyrone Lowery. Race Over Empire: Racism and U.S. Imperialism, 1865-1900. Chapel Hill: University of North Carolina Press, 2004.

Schulzinger, Robert D. A Time for Peace: The Legacy of the Vietnam War. Oxford and New York: Oxford University Press, 2006.

Shneer, David. Yiddish and the Creation of Soviet Jewish Culture, 1918-1930. Cambridge, U.K., and New York: Cambridge University Press, 2004.

Weston, Timothy B. The Power of Position: Beijing University, Intellectuals, and Chinese Political Culture, 1898-1929. Berkeley Series in Interdisciplinary Studies of China. Vol. 3. Berkeley: University of California Press, 2004.

Zeiler, Thomas W. Unconditional Defeat: Japan, America, and the End of World War II. Total War. Vol. 2. Wilmington, Del.: SR Books, 2004.

\section{Notes}

1. John McDonald, “The Book is Dead," in Charleston Conference Proceedings, 2001, ed. Katina Strauch (Westport, Conn.: Libraries Unlimited, 2003), 144.

2. Jennifer E. Knievel and Charlene Kellsey, "Citation Analysis for Collection Development: A Comparative Study of Eight Humanities Fields," Library Quarterly 75, no. 2 (Apr, 2005): 143; also see R. Watson-Boone, "The Information Needs and Habits of Humanities Scholars," RQ 34, no. 2 (Winter 1994): 203-16 for a review of nine previous studies including the book versus journal issue as well as age of citations.

3. McDonald, "The Book is Dead," 146.

4. Peter Williams and others, "The Role and Future of the Monograph in Arts and Humanities Research," Aslib Proceedings: New Information Perspectives 61, no. 1 (2009): 67-82, available online at www.emeraldinsight.com/info/journals/ap/ap.jsp [accessed 13 October 2011].

5. Peter Williams and others, "The Role and Future of the Monograph in Arts and Humanities Research," 73.

6. Vincent Lariviere and others, "The Place of Serials in Referencing Practices: Comparing Natural Sciences and Engineering with Social Sciences and Humanities," Journal of the American Society for Information Science and Technology 57, no. 8 (June 2006): 997-1004, available online at www.interscience.wiley.com [accessed 13 October 2011].

7. Knievel and Kellsey, “Citation Analysis for Collection Development," 154-63.

8. J.W. Thompson, "The Death of the Scholarly Monograph in the Humanities? Citation Patterns in Literary Scholarship," Libri 52, no. 3 (Sept. 2002): 121-36.

9. Richard Heinzkill, "References in Scholarly English and American Literary Journals Thirty Years Later: A Citation Study," College \& Research Libraries 68, no. 2 (Mar. 2007): 141-53.

10. John Cullars, "Citation Characteristics of English-Language Monographs in Philosophy," Library and Information Science Research 20, no. 1 (1998): 41-68.

11. Knievel and Kellsey, "Citation Analysis for Collection Development," 162.

12. Robert Alan and others, "Approval Plan Profile Assessment in Two Large ARL Libraries: University of Illinois at Urbana-Champaign and Pennsylvania State University," Library Resources \& Technical Services 54, no. 2 (Apr. 2010): 64-76.

13. Anne K. Beaubien, "ARL White Paper on Interlibrary Loan," Association of Research Libraries, available online at www.arl.org/bm doc/ARL_white_paper_ILL_june07.pdf [accessed 14 January 2011].

14. A. Henderson, "The Library Collection Failure Quotient: The Ratio of Interlibrary Borrowing to Collection Size," Journal of Academic Librarianship 26, no. 3 (May 2000), 159-70.

15. William S. Brockman and others, "Scholarly Work in the Humanities and the Evolving Information Environment," portal: Libraries and the Academy 3, no. 1 (Jan. 2003), 165-67.

16. Calculated by the authors from data provided in Table 2 of McDonald, "The Book is Dead," 147.

17. Knievel and Kellsey, "Citation Analysis for Collection Development," 154-63. 